\title{
REFERENCES
}

Belin, P. (1926). Bull. Soc. Chim. biol., Paris, 8, 1081.

Bernheim, F. (1942). J. Bact. 44, 533.

Birkinshaw, J. H. \& Raistrick, H. (1931). Philos. Trans. B, 220, 11.

Bloor, W. R. (1929). J. biol. Chem. 82, 273.

den Dooren de Jongh, L. E. (1926). Ned. Tijdschr. Hyg. $1,136$.

Fink, H., Haehn, H. \& Hoerburger, W. (1937). Chem. Ztg, 61, 689, 723, 744.

Fiske, C. H. \& Subbarow, Y. (1925). J. biol: Chem. 66, 375.

Friedemann, T. E. \& Graeser, J. B. (1933). J. biol. Chem. 100, 291.

— \& Klaas, R. (1936). J. biol. Chem. 115, 4.

Haehn, H. \& Kintoff, W. (1926). Chem. Zelle, 12, 115.

Kleinzeller, A. \& Trim, A. R. (1944). Analyst, 69, 241.

Krebs, H. A., Smyth, D. H. \& Evans, E. A. (1940). Biochem. J. 34, 1041.

Kumagawa, M. \& Suto, K. (1908). Biochem. Z. 8, 212.

Lane, J. H. \& Eynon, L. (1923). J. Soc.chem. Ind., Lond., 42, $32 \mathrm{~T}$.

Lemeland, P. (1923). Bull. Soc. Chim. biol., Paris, 5, 110.

Lindner, P. (1922). Z. angew. Chem. 35, 110.

Lodder, J. (1934). Die anascosporogenen Hefen. Amsterdam: N. V. Noord-Hollandsche Uitge vers maatschapij.

Longenecker, H. E. (1941). Biol. Symposia, 5, 99.

Lundsgaard, E. (1930). Biochem. Z. 220, 8.

Macf̣arlane, M. G. (1936). Biochem. J. 30, 1369.

(1939). Biochem. J. 33, 565.

McHenry, E. W. \& Gavin, G. (1941). J. biol. Chem. 138, 471.

Magnus-Levy, A. (1925). Oppenheimers Handb. Biochem. 8, 461. Jena: Fischer.

Mann, T. (1943). Nature, Lond., 151, 619.

Meyerhof, O. \& Boyland, E. (1931). Biochem. Z. 237, 406.
Miller, B. F. \& Van Slyke, D. D. (1936). J. biol. Chem. 114, 583.

Nägeli, C. \& Loew, O. (1878). Liebigs Ann. 193, 322.

Ohlmeyer, P. \& Ochoa, S. (1937). Biochem. Z. 298, 338.

Perlmann, I. \& Chaikoff, I. L. (1939). J. bial. Chem. 127, 211.

Prescott, S. C. \& Dunn, C. G. (1940). Industrial Microbiology. New York and London: MacGraw Hill, Inc.

Raaf, H. (1941). Cited in Chem. Zbl. (1942), 113, I, 3217.

Reichel, L. \& Reinmuth, W. (1938). Biochem. Z. 299, 359.

Rippel, A. (1943). Naturwissenschaften, 31, 248.

Rosenmund, K. W. \& Kuhnhenn, W. (1923). Z. Untersuch. Nahr.- u. Genussm. 46, 154.

Smedley MacLean, I. (1922). Biochem. J. 16, 370.

_ \& Hoffert, D. (1923). Biochem. J. 17, 720.

(1924). Biochem. J. 18, 1273. (1926). Biochem. J. 20, 343.

Smythe, C. V. (1938). J. biol. Chem. 126, 635.

Stephenson, M. (1939). Bacterial Metabolism. London: Longmans, Green and Co.

- \& Krebs, H. A. (1941). Ann. Rep. Prog. Chem. 38, 257.

— \& Whetham, M. D. (1922). Proc. Roy. Soc. B, 93, 262.

- (1923). Proc. Roy. Soc. B, 95, 200.

Terroine, E. F. \& Bonnet, R. (1927). Bull. Soc. Chim. biol., Paris, 9, 588.

Thaysen, A. C. \& Morris, M. (1943). Nature, Lond., 152 , 526.

Tošić, J. \& Krebs, H. A. (1943). Biochem. J. 37, Proc. xv.

Van Slyke, D. D. \& Folch, J. (1940). J. biol. Chem. 136, 509.

Warburg, O. \& Yabusoe, M. (1924). Biochem. Z. 146, 380.

\section{The Microbiological Degradation of Steroids}

\section{OXIDATION OF CHOLESTEROL BY PROACTINOMYCES SPP.}

\author{
By G. E. TURFITT, The Home Office Forensic Science Laboratory, Nottingham
}

(Received 6 September 1944)

The identification has been recorded (Turfitt, 1944) of species of the genus Proactinomyces as the bacterial agencies concerned in the disappearance of cholesterol from soils. Although many soil samples have been examined, no evidence has yet been adduced that any other bacteria, moulds or actinomycetes are able to accomplish this sterol breakdown; the possibility of the existence of cholesterol-decomposing organisms which do not grow on ordinary solid nutrient media is still being investigated. This apparently unique characteristic of
Proactinomyces is the more interesting in view of the taxonomic position of the organisms. Classification within the Order Actinomycetales involves a gradation through the unbranched Mycobacterium and Corynebacterium to the richly branching Actinomyces, the genus Proactinomyces constituting an intermediate transitional stage. Since bacterial cells are, with few exceptions (Sifferd \& Anderson, 1936), entirely devoid of any sterols, whilst the latter are actually synthesized by the yeasts and mould fungi, it is remarkable that one small section of the Natural 
Order serving as a connecting link between the two groups should apparently be specific in effecting the catabolism of sterols.

The wide distribution of Proactinomyces spp. in well-aerated, fertile soils is in accord with their strictly aerobic character, and the utilization of cholesterol by the organisms when grown in pure culture with cholesterol as sole carbon source must be attributed to oxidation processes. Chemical oxidation of the cholesterol molecule has yielded a variety of products, and has amply demonstrated the close interrelationship between the sterols, the sex hormones and the bile acids (Fieser, 1937). In addition to such changes, which involve oxidetive disruption of the side-chain, usually simultaneously with certain slight nuclear changes, it has recently been shown that the $C_{7}$ position is particularly susceptible to oxidation under relatively mild conditions. Thus, Bergström \& Wintersteiner (1941, $1942 a, b, c)$ have isolated 7-hydroxy- and 7-ketoderivatives after aeration of cholesterol in colloidal aqueous solution at $85^{\circ}$, whilst similar results have been obtained by Windaus, Bursian \& Riemann (1941) by photo-oxidation of cholesterol. In all these oxidations the cholane ring system has remained intact, but opening of ring $A$ is readily accomplished by the hypobromite or ozone oxidation of $\Delta^{4}$-cholestenone first described by Windaus (1906) prior to the establishment of the present sterol structure. It is a reasonable assumption that the microbiological oxidation follows an analogous course in that the molecule is again attacked at one or more of these vulnerable points. The necessary energy and available carbon required for continued bacterial growth is then derived from relatively simple degradation products split off from the parent structure.

\section{EXPERIMENTAL}

Rate of cholesterol degradation in vitro by

\section{P. erythropolis Gray \& Thornton}

A characteristic feature of the growth of Proactinomyces spp. on cholesterol with $\mathrm{NH}_{4} \mathrm{NO}_{3}$ as nitrogen source is the acid reaction of the medium after 4-7 days. Substitution of $\left(\mathrm{NH}_{4}\right)_{2} \mathrm{SO}_{4}$ for $\mathrm{NH}_{4} \mathrm{NO}_{3}$ again leads to the production of acid, which may thus arise from the liberation of acidic ions due to preferential utilization of the $\mathrm{NH}_{4}^{+}$radical. Support is given to this view by the fact that if $\mathrm{KNO}_{3}$ replaces $\mathrm{NH}_{4} \mathrm{NO}_{3}$ in the medium, the latter gradually becomes slightly alkaline. At the same time, this hypothesis does not preclude the possibility of the simultaneous production of a water-soluble organic acid, a factor which would account for the alkalinity due to liberated basic ions never becoming very marked.

With a view to determining the optimum conditions for cholesterol decomposition, the rate of disappearance of cholesterol from $P$. erythropolis cultures has been investigated using three different media of known composition:

(a) Medium I: $\mathrm{NH}_{4} \mathrm{NO}_{3} \quad 0.1 \% ; \quad \mathrm{K}_{2} \mathrm{HPO}_{4}$ $0.025 \% ; \mathrm{MgSO}_{4} .7 \mathrm{H}_{2} \mathrm{O} 0.025 \% ; \mathrm{NaCl} 0.0005 \%$; $\mathrm{FeSO}_{4} .7 \mathrm{H}_{2} \mathrm{O} 0.00001 \%$ in water.

(b) Medium II: medium I+ 0.5\% $\mathrm{CaCO}_{8}$.

(c) Medium III: as medium I but with $\mathrm{KNO}_{3}$ instead of $\mathrm{NH}_{4} \mathrm{NO}_{3}$.

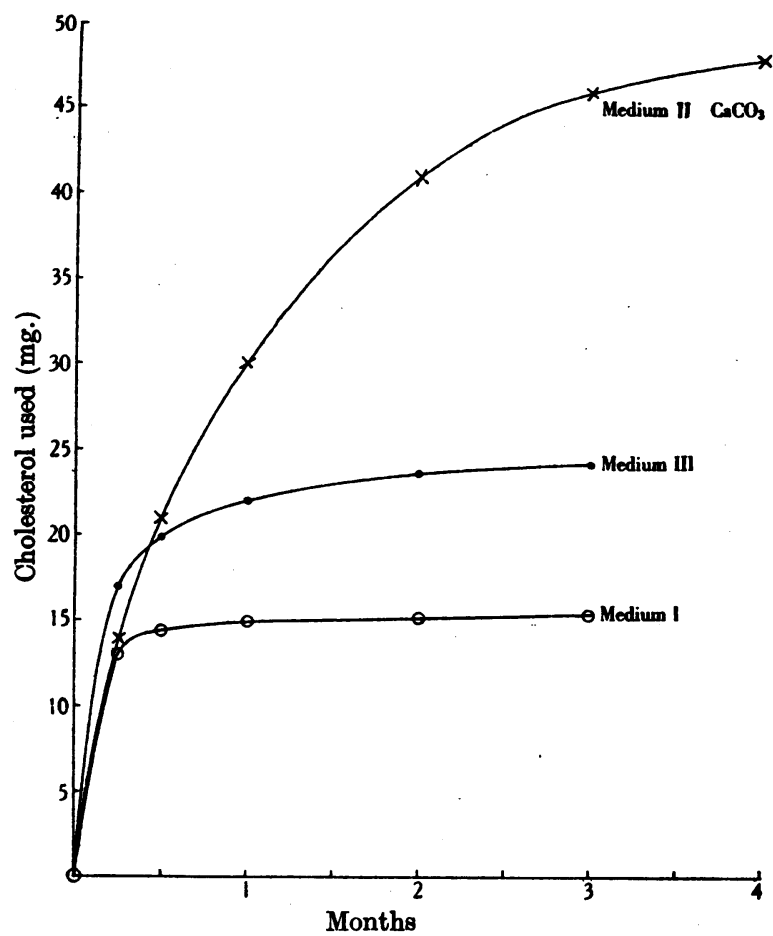

Fig. 1. Destruction of cholesterol by $\boldsymbol{P}$. erythropolis cultures on synthetic media. For composition of media, see text. Temperature $25^{\circ}$.

Thirty-two $250 \mathrm{ml}$. conical culture flasks, each containing $100 \mathrm{ml}$. of the appropriate mineral salt solution, were autoclaved for $15 \mathrm{~min}$. at $115^{\circ}$. $50 \mathrm{mg}$. finely powdered sterile cholesterol were added with aseptic precautions to each of the flasks, which were then inoculated with $0.5 \mathrm{ml}$. quantities of a suspension of $\boldsymbol{P}$. erythropolis containing approx. 20 million viable organisms per ml. Sixteen of these flasks were incubated at $25^{\circ}$ in darkness, whilst the remaining sixteen were maintained at the same temperature in diffused light. Throughout the incubation period the flasks were gently shaken every $24 \mathrm{hr}$. At definite intervals, two flasks (duplicates) from each batch of sixteen were removed. These cultures were extracted thoroughly with $\mathrm{CHCl}_{3}$, the extracts from each culture dried with anhydrous $\mathrm{Na}_{2} \mathrm{SO}_{4}$ and made up to $100 \mathrm{ml}$. in a graduated flask.

The colorimetric determination of residual cholesterol in these solutions was carried out by a meihod essentially similar to that previously described (Turfitt, 1943), but 
with slight differences in technique which considerably reduce the tedious nature of the analysis. A measured portion of each solution, containing approx. $0.5 \mathrm{mg}$. of oholesterol, was evaporated to dryness in a $15 \mathrm{ml}$. centrifuge tube, and the residue taken up in $1 \mathrm{ml}$. ether. $4 \mathrm{ml}$. of a $0.2 \%$ solution of digitonin in $95 \%$ ethanol were added, and the mixture concentrated to $3 \mathrm{ml}$. After standing overnight in the refrigerator, the white flocculent deposit was centrifuged off and washed three times with cold ether-acetone (1:2). $7 \mathrm{ml}$. benzene were added, and the solution was refluxed gently for $45 \mathrm{~min}$. to decompose the digitonide, and then concentrated to $3 \mathrm{ml}$. Digitonin was precipitated by the addition of $9 \mathrm{ml}$. petroleum, b.p. $40-50^{\circ}$, centrifuged off after standing for 10 min., and washed three times with petroleum. The solution and petroleum washings were pooled, evaporated to dryness, and taken up in $5 \mathrm{ml}$. chloroform in a $10 \mathrm{ml}$. glass-stoppered cylinder. $0.5 \mathrm{mg}$. cholesterol dissolved in $5 \mathrm{ml}$. chloroform was measured into a second cylinder, and $1.0 \mathrm{ml}$. acetic anhydride and $0.1 \mathrm{ml}$. conc. $\mathrm{H}_{2} \mathrm{SO}_{4}$ added to each. After thorough mixing, each solution was allowed to stand in a bath at $25^{\circ}$ for 15 min., the green colours being then compared in a colorimeter.

The results of these experiments are shown graphically in Fig. 1. No appreciable difference was observed between the flasks incubated in darkness and the corresponding ones exposed to light. The duplicate flasks examined at each time interval gave very closely concordant results.

In the unbuffered Media I and III the pH change occurring towards the seventh day brings about a marked decline in the degradation process, this decline being rather more evident where the change is a lowering of the $\mathrm{pH}$ value. In the presence of $\mathrm{CaCO}_{3}$ to counteract acidity (Medium II), however, this relatively abrupt break in the curve is not experienced. The importance of the $\mathrm{pH}$ factor is thus experirnentally established, and this, in conjunction with the obligatory aerobic nature of the organisms, provides a clear explanation of their relative rarity in acid peaty soils, and their abundance in aerated, lime-treated arable land.

\section{Oxidation of cholesterol by Proactinomyces spp.}

Since provision for the neutralization of acids was essential for any continued attack on the cholesterol molecule, the medium employed in an attempt to identify the reaction products had evidently to be buffered in some manner. The $\mathrm{CaCO}_{3}$ used in the above work possessed obvious advantages, but it suffered from the inherent defect that it introduced a further source of carbon. Thus, before its use could be justified it was necessary to ascertain whether Proactinomyces spp. could utilize this inorganic carbon. In a series of carefully controlled experiments this point was investigated, but no evidence of any autotrophic character was detected.

For the preliminary large-scale work, a hundred $250 \mathrm{ml}$. conical culture flasks, each containing $100 \mathrm{ml}$. Medium I and approx. $1 \mathrm{~g} \cdot \mathrm{CaCO}_{3}$, were autoclaved for $15 \mathrm{~min}$. at $115^{\circ}$, and to each flask was added approx. $0.5 \mathrm{~g}$. finely powdered sterile cholesterol. After inoculation with a heavy aqueous suspension of $P$. erythropolis prepared from a $24 \mathrm{hr}$. agar slope culture, the flasks were incubated in darkness at $25^{\circ}$ for 1 month. At the end of this time the cultures were filtered at the pump on $18.5 \mathrm{~cm}$. Whatman no. 5. filters, and the filtrate shaken mechanically with three successive 1 1. quantities of ether to remove neutral fat. The bulk of aqueous liquid was then adjusted to $\mathrm{pH} 4$ with dilute $\mathrm{H}_{2} \mathrm{SO}_{4}$, and again thoroughly extracted with 1 l. quantities of ether. On evaporating this extract, after freeing from acid and drying with anhydrous $\mathrm{Na}_{2} \mathrm{SO}_{4}$, there were obtained $82 \mathrm{mg}$. of a yellowish oil (A) with a sharp, 'fatty acid' odour.

The residue from filtration of the cultures was dried at $60^{\circ}$, powdered, and extracted in a Soxhlet with ethanol for $48 \mathrm{hr}$. After this extraction there remained a mass consisting largely of $\mathrm{CaCO}_{3}$, and of bacterial debris. Since this mass should also contain any insoluble $\mathrm{Ca}$ salts of organic acids produced during the bacterial action, it was accordingly acidified with dilute $\mathrm{H}_{2} \mathrm{SO}_{4}$ and the turbid suspension extracted continuously with ether for $8 \mathrm{hr}$. The washed and dried ether extract gave, on evaporation, $137 \mathrm{mg}$. of a brownish gum (B) from which a white amorphous solid tended to separate. The yellow ethanol solution from the Soxhlet extraction was separated by means of Girard's ' $T$ ' reagent into ketonic and non-ketonic fractions. The latter gave $21.4 \mathrm{~g}$. of unchanged cholesterol, whilst the ketonic fraction, decolorized with charcoal and recrystallized twice from methanol-acetone (3:2), yielded $22.7 \mathrm{~g}$. white needles, m.p. $80^{\circ}$. In a mixed m.p. determination with an authentic specimen of $\Delta^{4}$-cholestenone the m.p. was not depressed. The compound was further characterized by means of the readily crystallized 2:4-dinitrophenylhydrazone. This derivative was obtained, after twice crystallizing from ethanol-benzene (1:1) as a mass of fine red rosettes, gradually changing to stout transparent prisms on standing, m.p. 233-234 ${ }^{\circ}$, not depressed in admixture with an authentic specimen of $\Delta^{4}$-cholestenone-2:4-dinitrophenylhydrazone. Found: $\mathrm{N}, 10 \cdot 2 \%$. Calc. for $\mathrm{C}_{33} \mathrm{H}_{48} \mathrm{O}_{4} \mathrm{~N}_{4}: \mathrm{N}, 10 \cdot 0 \%$.

The initial stage of the bacterial attack on cholesterol is thus an oxidation of the $-\mathrm{OH}$ at $\mathrm{C}_{3}$, accompanied by a rearrangement of the double bond to the 4:5 position. This formation of $\Delta^{4}$-cholestenone is considered to result from the action of a dehydrogenase system in the cells of the inoculum; it represents merely a transfer of an atom of $\mathrm{H}$, and does not involve the loss of either nuclear or sidechain carbon. Since bacterial growth continues actively, there must be a secondary action whereby either $\Delta^{4}$-cholestenone is itself decomposed, or less probably, some unchanged cholesterol is oxidized in an alternative manner which yields a source of available carbon. In either event, the multiplying bacterial cells provide for further enzymic oxidation to $\Delta^{4}$-cholestenone. Thus, in the earlier stages of the action it is this ketone which is the predominating product in the cultures. The small fractions (A) and (B) undoubtedly contain actual degradation products of the original sterol, but in this preliminary work the quantities available were insufficient to 
permit of any serious attempt to isolate individual chemical entities.

The choice of $P$. erythropolis for this work was decided by the fact that it is by far the most frequently encountered species in the isolation of these cholesterol-decomposing organisms from soils. However, the activity of all the known Proactinomyces spp. (cultures of which have been obtained from the National Collection of Type Cultures, Lister Institute) has been investigated in a similar manner. Each organism was inoculated into a 11 . conical culture flask containing $250 \mathrm{ml}$. Medium I, together with $1 \mathrm{~g}$. $\mathrm{CaCO}_{3}$ and $2 \mathrm{~g}$. cholesterol, and the cultures incubated at $25^{\circ}$ for 1 month. Extraction of the cultures as outlined above yielded, $\Delta^{4}$-cholestenone in every instance, although there was a wide variation in the yield obtained with the various species.

\section{Isolation of $\Delta^{4}$-cholestenone from soil treated with cholesterol}

The oxidation of cholesterol to $\Delta^{4}$-cholestenone by Proactinomyces spp. when grown in pure culture as described above occurs under conditions vastly different from those obtaining in situ, where the soil abounds with alternative carbon sources. In order to determine whether the oxidation follows the same course under natural conditions, $1.0 \mathrm{~g}$. finely divided cholesterol was intimately mixed with $100 \mathrm{~g}$. of a medium loam in a $250 \mathrm{ml}$. beaker, and buried below the ground surface in the soil from which the sample was taken. After 1 month, the experimental soil was removed from the ground, dried in an air-oven at $60^{\circ}$, and powdered in a mortar. By continuous extraction with acetone there were obtained $3.2 \mathrm{~g}$ : of a brownish gummy residue which yielded $0.85 \mathrm{~g}$. of unsaponifiable matter. The ketonic fraction, separated by means of Girard's ' $T$ ' reagent, was a thick, yellow oil $(0.217 \mathrm{~g}$.$) , gradually setting to a solid mass on cool-$ ing in ice. Repeated crystallization from methanolacetone (3:2) gave almost colourless needles, m.p. $78-79^{\circ}$, not depressed in admixture with $\Delta^{4}$. cholestenone. The 2:4-dinitrophenylhydrazone crystallized from ethanol-benzene (1:1) in red rosettes, m.p. and mixed m.p. 233-234. Found: N, 10.2\%. Calc. for $\mathrm{C}_{38} \mathrm{H}_{48} \mathrm{O}_{4} \mathrm{~N}_{4}: \mathrm{N}, 10 \cdot 0 \%$.

\section{Oxidation of cholesterol by Proactinomyces spp. in ordinary culture media}

In the experiments hitherto reported on microbiological oxidation in the sterol-sex hormone field, the steroid side-chain appears to exert a completely inhibitive influence on the action. Thus, Mamoli (1938) has described a bacterial mixture which, when cultured on Milan yeast, has smoothly converted dehydroandrosterone into androstenedione, and 3-pregnenol-20-one into progesterone; but cholesterol was completely unchanged. These results have been confirmed, and other steroid derivatives investigated, by Ercoli $(1940,1941)$ using Micrococcus dehydrogenans cultured on a buffered yeast extract.

Since $P$. erythropolis readily converts cholesterol into $\Delta^{4}$-cholestenone in soil cultures, it was con. sidered likely that the oxidation would also result in ordinary liquid culture media. Lemco broth and yeast water, both adjusted to $\mathrm{pH} 7 \cdot 6$, were selected for the experiment, and $100 \mathrm{ml}$. quantities of these were placed in $250 \mathrm{ml}$. conical culture flasks. The flasks were autoclaved for $15 \mathrm{~min}$. at $115^{\circ}$, and $1 \mathrm{~g}$. sterile powdered cholesterol was introduced into each. After inoculation with $P$. erythropolis, the flasks were incubated at $25^{\circ}$ for 1 month. Extraction of the cultures with ether after this period gave, in both instances, an almost colourless crystalline mass. Separation of the ketonic fraction by means of the Girard ' $T$ ' reagent yielded 0.17 and $0.20 \mathrm{~g}$. of slightly yellow crystalline solid from the broth and yeast water cultures respectively. $\Delta^{4}$-Cholestenone was isolated in each case by crystallization of the ketonic residues from methanol-acetone (3:2), and characterized as its 2:4-dinitrophenylhydrazone.

\section{DISCUSSION}

Whilst no detailed results are yet available of the action of $P$. erythropolis on other steroid compounds, the oxidizing action of this organism is evidently not influenced by the presence of the side-chain to an extent comparable with that reported for $M$. dehydrogenans. These facts are of interest in connexion with the fate of ingested cholesterol. The former view that coprosterol originates by direct bacterial hydrogenation of cholesterol in the alimentary tract has received no experimental support, and it is now considered (Rosenheim \& Starling, 1933; Rosenheim \& Webster, $1943 a, b$ ) that the conversion occurs in two stages, $\Delta^{4}$-cholestenone being the actual precursor of coprosterol. The possibility of the intestinal flora and fauna participating in the process has been closely investigated by these workers, who conclude that bacterial and protozoal agencies are probably not involved in either the oxidation or reduction stages. Although the discovery of the oxidation of cholesterol by Proactinomyces spp. appears to raise some superficial objections to this conclusion, it is doubtful whether any appreciable quantity of $\Delta^{4}$-cholestenone arises in this manner in vivo. The author, in some as yet uncompleted experiments on this subject, has isolated $P$. erythropolis from lettuce, strawberries and other uncooked, edible produce, so that a number of these organisms may be assumed to be ingested with certain foodstuffs. The number of such organisms, however, must be relatively small, and will certainly be 
further reduced by the highly acid conditions prevailing in the stomach. Any oxidation which these bacteria may accomplish in the alimentary canal will probably occur during passage through the small intestine, but it is extremely doubtful whether in this limited time more than a small percentage of the sterol would be oxidized. All attempts to recover the organisms from faeces have proved unsuccessful. In the case of the guinea-pig, the caecum has recently been identified (Schmidt \& Hughes, 1942) as a principal site of the catabolism of cholic acid, the - $\mathrm{OH}$ groups of which are oxidized with formation of the corresponding keto-compounds. This oxidation is of a bacterial nature, as shown by the ability of Alcaligenes faecalis Casteliani \& Chalmers, isolated from the caecal contents, to effect the same oxidations in vitro (Schmidt, Hughes, Green \& Cooper, 1942). The organism, cultured in serum, also oxidizes lithocholic acid and dehydroisoandrosterone to the corresponding keto-compounds (Hughes \& Schmidt, 1942). In the author's experiments, neither $A$. faecalis nor the mixed flora of the human caecum has brought about the oxidation of cholesterol. The question, however, whether $\Delta^{4}$. cholestenone production in vivo is essentially a bacterial oxidation, or whether it results from the enzymic activity of alimentary secretions, still cannot be regarded as settled.

\section{SUMMARY}

1. Cholesterol degradation by Proactinomyces erythropolis Gray \& Thornton in vitro was greatly influenced by $\mathrm{pH}$ changes in the medium. In buffered media, disappearance of cholesterol was almost complete in 4 months.

2. All Proactinomyces spp. tested experimentally oxidized cholesterol to $\Delta^{4}$-cholestenone in a varying degree when grown in mineral salt solution with the sterol as sole organic carbon source. It is concluded that oxidation of some of the sterol is effected by the cells of the inoculum, and that actual degradation of the molecule then occurs to provide available carbon for continued bacterial growth. Further oxidation to $\Delta^{4}$-cholestenone then occurs, and the process continues until the whole of the cholesterol has disappeared. Certain fractions representing degradation products have been isolated in largescale experiments, but not as yet identified.

3. Oxidation to $\Delta^{4}$-cholestenone also resulted when cholesterol intimately mixed with garden soil was buried in the ground for 1 month.

4. In spite of evidence that Proactinomyces spp. are taken into the alimentary tract with certain foodstuffs, it is considered unlikely that these organisms play any appreciable role in the formation of $\Delta^{4}$-cholestenone in vivo.

\title{
REFERENCES
}

Bergström, S. \& Wintersteiner, O. (1941). J. biol. Chem. $141,597$.

- (1942a). J. biol. Chem. 143, 503.

(1942b). J. biol. Chem. 145, 309.

(1942c). J. biol. Chem. 145, 327.

Erçoli, A. (1940). Boll. sci. facolta chim. ind. Bologna, p. 279. (1941). Hoppe-Seyl. Z. 270, 266.

Fieser, L. F. (1937). The Chemistry of Natural Products related to Phenanthrene, p. 251. New York: Reinhold Publishing Corporation.

Hughes, H. B. \& Sohmidt, L. H. (1242). Proc. Soc. exp. Biol., N.Y., 51, 162.

Mamoli, L. (1938). Ber. dtsch. chem. Ges. 71, 2701.

Rosenheim, O. \& Starling, W.W. (1933). Chem. Ind. 48, 238.
Rosenheim, O. \& Webster, T. A. (1943a). Biochem. J. 87, 513.

(1943b). Biochem. J. 37, 580.

Schmidt, L. H. \& Hughes, H. B. (1942). J. biol. Chem. 148, 771. 145, 228.

Sifferd, R. H. \& Anderson, R. J. (1936). Hoppe-Seyl. Z. 289, 270.

Turfitt, G. E. (1943). Biochem. J. 37, 115.

- (1944). 'J. Bact. 47, 487.

Windaus, A. (1906). Ber. dtsch. chem. Ges. 89, 2008.

- Bursian, K. \& Riemann, U. (1941). Hoppe-Seyl. Z. 271, 177.

\section{The Utilization of Urea in the Bovine Rumen}

\section{THE ISOLATION OF THE SYNTHESIZED MATERIAL AND THE CORRELATION BETWEEN PROTEIN SYNTHESIS AND MICROBIAL ACTIVITIES}

\author{
By J. A. B. SMITH, The Hannah Dairy Research Institute, Kirkhill, Ayr
} AND F. BAKER (Plimmer Research Fellow), The County Technical College, Guildford

\section{(Received 22 September 1944)}

Pearson \& Smith (1943) showed that when the liquid contents of the bovine rumen were incubated in vitro in the presence of certain carbohydrates a decrease in the non-protein nitrogen content of the liquid occurred. This decrease was assumed to result from protein synthesis, and since the rate of decrease could be controlled by the addition of toxic substances, the protein synthesis was attributed to 